\title{
The Ups and Downs of the Nigerian Society: A Satirical View on Socio-political Matters in Chimamanda Ngozi Adichie's Purple Hibiscus (2004) and Sefi Atta's a Bit of Difference (2013)
}

\author{
Babacar Diakhaté \\ Laboratoire d'Études africaines et postcoloniales, Université Cheikh Anta Diop, Dakar, Sénégal \\ diakhatebabacar83@hotmail.fr
}

\begin{abstract}
This paper aims to show the objectivity of Nigerian writers by portraying the ups and downs of their society. Indeed, in Sefi Atta's a Bit of Difference and Chimamanda Ngozi Adichie's Purple Hibiscus, the authors have done a diagnosis without complaisance of the bottlenecks that impede Nigeria from moving forwards. It also demonstrates that feminist activism can challenge a political military power. It finally displays that violence at universities; social injustice, corruption and mediocrity are the evils that characterized the Nigerian society.
\end{abstract}

Keywords : activism; patriotism; education; corruption; mediocrity

\section{Introduction}

Most of the "Afropean" female writers such as Sefi Atta, Chimamanda Ngozi Adichie and Chika Unigwe have devoted many of their literary productions to emigration and the promotion of "homecoming". In their respective writings like News From Home and Swallow, Half of a Yellow Sun and On Black Sisters Street, these authors portray the bad living condition in which African immigrants are placed. However, in Sefi Atta's A Bit of Difference and Chimamanda Ngozi Adichie's Purple Hibiscus they show through their fictions that women are not only interested in their own concern but rather in the well-running of their society. Firstly, this article aims at proving that the sense of activism and patriotism is also another dimension of feminism to challenge a military power. Secondly, it satirically castigates a society characterized by an inadequate educational system, social injustice and corruption. And finally, the paper denounces the way in which some Nigerians use foundations and NGOs to solve their own problems to the detriment of the deserving populations.

\section{Review of Literature}

\section{Promoting Activism and Patriotism to Challenge a Dictatorial Political System Under the Cover of Democracy}

Activism and patriotism can positively contribute to the transformation of a country. Patriotism is also part and parcel of the dimension of women feminism. There is patriotism when a person nurtures the feeling of love, pride and devotion to a homeland and the sense of alliance with other citizens who share the same values. Joan S. Ford, Bremerton defines patriotism celebrates a country's strengths, but recognizes its failures and attempts to correct them. Furthermore, Chinua Achebe in The Trouble with Nigeria, defines a "patriot" not as a person who only says I love my Country, he is not a person who shouts, swears and sings his love of his country. According to Achebe, a patriot is someone who cares deeply about the happiness and the well-being of his country and its people. He argues that patriotism should start with the roughness of Nigerian political leaders by taking the example of Murtala Muhammed, who, during his presidency all the civil servants joined their places of work at $7 \mathrm{~h}$ 
30 in spite of the traffic jam. He asserts that Nigeria discovers changes with only leaders who have the will, ability and vision. For Achebe, the problem does not lie neither in the climate nor in the natural elements, but rather in the bad attitude of Nigerians. In Muhammed Abdullahi Tosin's first prize winning essay, on the occasion of the NOA (National Orientation Agency) essay competition entitled What Nigeria Means To Me (2013) admits that the question of "what does Nigeria mean" has evoked a mixed basket of comments both optimistic and pessimistic.

According to Tosin, the mixed pessimistic opinions are related to the socio-economic conditions of Nigerian citizens. In What Nigeria Means To Me, Muhammed defends that Nigeria means a giant of Africa by displaying to what extent Nigeria is culturally, linguistically and religiously influential to the rest of Africa. He shows how the industries of music and films have been the choice of entertainment in many of their neighboring countries such as Cameroun, Kenya and Malawi. Nigerian indigenous musicians like P-Quare, Davido, Inyanya and Tuface have captured the musical tastes of Africa's youth from Dakar to Johannesburg. In this same vein of cultural contribution, Abdullahi also shows Nigerian intellectuals and icons who undeniably contribute to the world literary production like Chinua Achebe, Chimamanda Ngozi Adichie, Wole Soyinka among others.

However, Muhammed has not been objective in his essay for he considers the political system to be a good one. According to him, Nigeria is a land where the freedom of speech prevails. To him, freedom is when people have the ability to do, write, say anything freely and overtly without fear of harassment and intimidation. He affirms that:

The freedom I enjoy freely is what citizens of some nations have craved and are still craving for. I have the right and freedom to be what. It is this freedom I enjoy which makes Nigeria a unique place to be (Abdullahi, 2013: 2).

Muhammed makes people believe that Nigeria is a perfect land, the place to be, but in reality no such a thing happens because Nigeria's political system ails. It is characterized by coups, corruption, nepotism, dictatorship, etc. This has triggered off Chimamanda Ngozi Adichie and Sefi Atta's motivations to promote patriotism and activism in order to change the system and eventually liberate a whole country. Sefi Atta and Chimamanda Ngozi Adichie have respectively shown in A Bit of Difference and Purple Hibiscus that, like patriotism, activism is also a dimension of feminism that is worth exploring.

Activism is very illustrated by Adichie in Purple Hibiscus through the character of Eugene, (Papa). Eugene rules an editorial entitled Standard in which he denounces a military power and the ills prevailing in Nigeria. His activism to denounce a political system finally makes him a victim of reprisal and incarceration. Moreover, Atta has also shown activism in Everything Good Will Come through the character of Enitan's father, Sunny, who, in turn leads Oracle Newspapers. It is because of activism, commitment and patriotism that Enitan's father is finally arrested. Women's activism is shown here by Enitan. Her mother puts: too bad for your father... he can't keep a family together, now he wants to save his country (Atta, 2004: 220); Enitan puts Grace Ameh, a human right activist, in charge of perpetuating the editorial so as to warn and raise consciousness of the public about the rampant evil of a military dictatorship.

What Beatrice (Eugene's wife) and Enitan have done in joining the Human Right Activists is just for the well-running of their nation. In joining the fight for democracy for a 
whole country rather than fighting only for their own interest is just the illustration that the $21^{\text {st }}$ century African woman has transcended feminism. In this regard Atta affirms that the salvation of the nation through multiplier effect will in turn lead to the salvation of the woman...Military dictatorship get out of my country (Atta, 2004: 293). Adichie uses Eugene's voice in Purple Hibiscus to epitomize her own voice when he informs his children that:

Coups begat coups, he said, telling us about the bloody coups of the sixties, which ended up in civil war after he left Nigeria to study in England. A always began a vicious circle. Military men...were all power drunk. Of course Papa told us, the politicians were corrupt...But what we Nigerians needed was not soldiers ruling us, what we needed was renewed democracy (Adichie, 2004: 24-5).

Enitan, Beatrice and Ifeoma's activism and patriotism have been fruitful because Enitan's father and Beatrice's husband have been released from incarceration. J. Akan, analyzing the work of Uzor Maxim Uzoatu asserts that: It is even worse for the woman in the society somewhat compels her to be more of a sitting duck without the rights to propel her own life (Uzoatu, 2011:87).

In addition, many Nigerians are disappointed with Obasanjo and accuse him of perpetuating Abacha's dictatorial political system. After his impeachment, Nigerian female writers keep denouncing a political system based on corruption, nepotism and social injustice. Like Atta and Adichie, Chika Unigwe also castigates the phenomenon of car importation that the president has forbidden. According to Sisi, this is social injustice because this car importation could allow the poorest population to have access to second-hand cars. Unigwe shows Sisi's frustration:

That President Self! While people are busy killing each other in senseless riots, he is busy banning the importation of everything. Tooth paste. Chloroquine for Malaria. Soaps. Detergents. Envelops. How am I ever supposed to buy a car? We thought we were suffering under Abacha. This is worse! At least a military dictatorship did not hide under the cover of democracy. This is worse (Unigwe, 2009:78)

Through activism and patriotism people are able to achieve their aims by challenging a military usurpation of political power epitomized by dictatorship.

\section{Discussion}

\subsection{Educational System Unrest}

Since the departure of European colonizers from the African land, the African political officials have done nothing to adapt the educational system in accordance with African realities. Therefore, many European colonies' educational system is always in turmoil. It is symbolized by inadequacy of teachings, violence, strikes, students' riots, etc. Chimamanda Ngozi Adichie's Purple Hibiscus denounces this phenomenon. In her novel, Adichie depicts the hard and bad living conditions in which the students of her country are placed. She asserts that the university has become the microcosm of the country because the complaints of the populations about lack of light, endless power cuts, no running water, etc; have some repercussions in the universities.

In A Bit of Difference, Atta confesses that Naija is too tough. No water, no light. Armed robbers are all over the place and people demanding money... Nigeria is the place to escape 
from (Atta, 2013: 25). This bad treatment of the students leads them to take to the streets carrying along with them placards under the effigies of Sole the administrator must go. He does not wear pant oh! Head of state must go. He doesn't wear pant oh! Where is running water? Where is light? Where is petrol? (Adichie, 2004:228). During the manifestation, students have set the administrator's house on fire; even the guesthouse has burned to the ground and six university cars have been burned down. Adichie blames the officials for not giving adequate responses and satisfaction to the demand of the students, which causes the closure of the university. Adichie asserts: the university was closed down until further notice as a result of damage to university property and the atmosphere of unrest (Adichie, 2004:229). These countless students' riots may have some negative impact on their levels. It is commonly admitted that the levels of many African students have remarkably dropped. In Purple Hibiscus, Adichie shows that most students cheat in order to succeed in their exam and this phenomenon has also other disasters in their future professional fields. She demonstrates how cheaters have managed to get the test ahead of time to get higher grades. Adichie displays the strategies adopted by some students to get into a house of a teacher at night to steal his grade book and copies of exams. Professor Okafor has killed his son Chidifu for stealing his exam papers to sell them to his father's students. Ifeoma said to her friend, Chiaker: Did you hear what happened to professor Okafor'son? "Okafor who lives on Funton Avenue. His son. Chidifu". He stole his father's exam papers and sold them to his father's students (Adichie, 2004:243). This is the laxity, nepotism and lack of consideration with which some African countries are managing their educational system.

\subsection{Social Injustice, Corruption and the Cult of Mediocrity}

Social injustice, corruption and the cult of mediocrity are the obstacles that really hinder many poor African countries to move forward. Indeed, social injustice may give rise to revolt and corruption, which leads the economy of a country to go down. Both evils have been objectively castigated by Nigerian intellectuals like Adichie, Atta and Achebe respectively in Purple Hibiscus, A Bit of Difference and the Trouble with Nigeria. Adichie and Atta promote the "home coming" of many European-born Nigerian immigrants. They impel them to come back home to invest in business and contribute to the development of Nigeria. But many Nigerian immigrants are doubtful about the atmosphere of a Nigerian corrupt system. In this regard Achebe owns up: keeping an average Nigerian from being corrupt is like keeping a goat from eating yam (Achebe, 1983:38). Achebe's quotation is echoed by Atta's A Bit of Difference, in which she demonstrates to what point, corruption has overwhelmed Nigeria. Atta asserts that:

You cannot explain about corruption in Nigeria. Members of your family are corrupt. Some of your friends are corrupt. The only people who claim they are not corrupt have not had the opportunity to be corrupt, which is why they explain they feel cheated in the midst of all the corrupt around them (Atta, 2013: 65).

Atta, Adichie and Achebe denounce the fact that salaries are given to non-existent workers and that money could have been used to build equipment like airports or schools. These non-existent workers are called "Ghost workers" by Achebe. Adichie argues that Corruption is even practiced in prisons because Celestine and Mama, while paying a visit to Jaja in prison, were obliged to bribe the guard. Adichie confesses that: 
Celestine places the bag of fruits on the counter in front of the guard. Inside is a magazine with an envelope stuffed full of crisp naira notes, fresh from the bank...the man puts his tooth pick down and grabs the bag. Then he leads Mama and me to an airless room with benches on both sides of a low table" one hour", he mutters before leaving (Adichie, 2004: 302).

Like Atta and Adichie, Unigwe in On Black Sisters Street depicts what some Nigerian people do when they need a degree and are unable to succeed. Most candidates resort to corruption by buying their exams or degrees. She probes that she could have succeeded in her SSCEs for long and gone to the University of her Choice if she had paid for that. Unigwe puts:

...If she had the money to pay someone to take the exam for her, she would have. Everyone was doing that. She knew people less deserving of a place at the university who had brought examination papers from corrupt JAMB officials and practiced at home or who had paid others to sit the examination for them (Unigwe, 2009: 124)

This quotation teaches both: a rotten corrupt system and social injustice against those who use the honest and righteous ways. Achebe castigates this injustice in the job seekers by giving the image between $\mathrm{A}$ and $\mathrm{B}$. According to him $\mathrm{A}$ has the competence but does belong to the wrong place. $\mathrm{B}$ has not the competence and belongs to the good tribe. Therefore the character B is finally given the vacant position. Who is the sufferer? To him, the nation is the only sufferer if the right man is not put at the right place.

\subsection{Business Humanitarianism}

African people are always praised by non-Africans thanks to their universal human values like solidarity, generosity, the sense of togetherness and spirituality. These values tend to disappear leaving the place to selfishness and paranoia. Sefi Atta, inspired by Nigeria, successfully, shows how her fellow citizens lose interest in helping the most vulnerable populations like the children and women affected by malaria and H.I.V. In $A$ Bit of Difference, she confirms that:

Women and children are especially vulnerable in Africa. Mothers become sex workers and they pass the virus to their babies. Babies die before they reach their second birthday. Grand mothers are raising orphans. It is awful what is going on. It makes you so angry (Atta, 2013:148).

This has engendered the frustration and anger of many African immigrants leading them to find some foundations or NGOs to have access to some sponsors to help their African most vulnerable populations. In A Bit of Difference, Deola and Kate Meade manage a foundation called LINK in England. It aims at preventing some diseases that are causing havocs in Nigeria such as Malaria and HIV. Atta displays Deola's programme:

One is to prevent malaria in children and the other is for women whose husbands have died from AIDS. The London office funds in Kenya, South Africa and other African countries that have a record for being what they call" fiscally reliable"...LINK money comes from well-meaning sources and goes out to well- deserving causes (Atta, 2013: 3).

However, these foundations and NGOs are reputed to be occasions on which their leaders satisfy their own business to the detriment of poor Africans. They create problems 
where they are not whatsoever in reality and resort to so-called foundations or NGOs to find financial solutions. Atta depicts this phenomenon through her character, Deola who gets finance from the foundation LINK in London and when she is in Lagos she sleeps at the hotel. She hosts her boyfriend, Wale, to enjoy their sex intercourse pretexting to celebrate her father's memorial in Nigeria. Deola's sex intercourse with Wale is proved by the HIV test she has done.

Please don't let me be HIV positive, I will be different if I leave this place

with negative result. I will I will I will I will change. I will be good to my family and friends I will counsel them. I will counsel everyone... I will obey your will. I will be respectful to my mother. I said I'll submit myself to you! What more do you want? (Atta, 2013: 135-6).

Through Deola's confession, Atta wants to warn young Africans about the danger of having sex intercourse with anybody. The moral lesson that must be derived from that is the return to African values such as abstinence until marriage, respect for our mothers and families and finally a strong devotion to God.

\section{Conclusion}

African Anglophone writers are always alleged to be very objective in their writings. They portray freely and fairly the society that has inspired them to produce fictions. Instead of painting the whole tree in white as Muhammed Abdullahi Tosin did in his essay entitled What Nigeria Means To Me (2013) on the occasion of the N.O.A essay competition by showing that Nigeria is the giant of Africa, praising their films and music industries, singers and freedom, the other Nigerian intellectuals show the ups and downs of their societies. In this regard, in The Trouble with Nigeria, Achebe has done a full diagnosis of the issues that hinder Nigeria from moving forward. Sefi Atta and Chimamanda Ngozi Adichie have echoed Achebe by doing a satirical portrayal of the Nigerian society. In A Bit of Difference and Purple Hibiscus, the writers have demonstrated that strong activism and patriotism can challenge a military power. They also castigate the Nigerian daily attitudes symbolized by violence, social injustice, mediocrity, corruption and embezzlement of public funds.

\section{References}

Achebe, Chinua, The Trouble with Nigeria, London, Heinemann, 1983.

Adichie, Chimamanda Ngozi, Purple Hibiscus, Anchor, 2004.

.. Half of a Yellow Sun, London, Fourth Estate, 2009.

Atta, Sefi, News From Home, Interlink Book, 2004.

.........Everything Good Will Come, interlink book, 2004.

........Swallow, Interlink Book, 2010.

........A Bit of Difference, Interlink Book, 2013.

Unigwe, Chika, Black Sisters Street, Random House, New York, 2009.

Tosin, Muhammed Abdullahi, What Nigeria Means To Me, $1^{\text {st }}$ Prize Winning Essay, 2013

NOA Essay Contest, December 31, 2013.

Uzoatu. M.U, Trials of the Single Nigerian Woman. Thursday. 87, November 13, 2011.

WWW. ngex.com/news/public/article.php?ArticleID:2003. 